\title{
Extension of Overall Node Battery Extra Availability in Ubicomp with Location-Aware MANET Transmission Compared to Direct Node-To-Node Transmission.
}

\author{
M. Kaleem GALAMALI, Assoc. Prof Nawaz MOHAMUDALLY
}

\begin{abstract}
The impact of location-tracking in mobile environments matters tremendously into performance of ubicomp functionalities and justifies research effort put in it [1-10]. Along with progresses in ubicomp, several questions will crop up and whose answers depend on components not yet put forward. Hence, empirical and simulator based supports to answer these questions are required as starting points. A prior such study was conducted to find trends of energy savings achievable by applying location-aware direct Node-To-Node (NTN) transmission strategies [2] from the perspective of overall nodes, whereby all user nodes in the topography contribute in routing tasks. Another follow-up study was carried out to model the trends of Overall Energy Savings achievable in location-aware MANET transmission [15] from the notion of all user nodes contributing to routing tasks of other user's transmissions, i.e. MANET nodes are NOT supplied as infrastructure.
\end{abstract}

Following these two studies $[2,15]$, the next level of investigation required is: "By What extra amount can overall nodes' battery availability be extended in locationaware ubicomp MANET transmission compared to direct Node-To-Node transmission? How does this extra amount vary over varying node numbers present in a topography for ubicomp?

The results of this study can serve towards better architecture formulations and alleviation of maintenance procedures required for ubicomp. This study follows from previous ones [1-64]

Key terms: Ubicomp- Ubiquitous Computing, MAUCMobile and Ubiquitous Computing, CBR- Constant Bit Rate, MANET- Mobile Adhoc Network, NTN- Node-To-Node, ESEnergy Savings, OES- Overall ES, OLNTNES- Overall Less NTN ES, EC-Energy consumed, OLNTNEC- Overall Less NTN EC, BAEF- Battery Availability Extension Factor, MBAEF- Mean BAEF.

M. Kaleem GALAMALI,

University of Technology Mauritius (student)

Mauritius

Assoc. Prof Nawaz Mohamudally

University of Technology Mauritius, Mauritius

\section{Introduction}

Ubicomp designers may find the knowledge of the trends of energy consumption and energy savings achievable in ubicomp crucial for optimising future architecture design. Designing better hardware batteries will not be sufficient if proper methods of using them are not well devised. Such methods also englobe algorithmic methods prone to extend their availability or uptime, one of which is application of locationawareness in transmission strategies. Two such strategies of concern here, were formerly investigated from simulation perspective: one was direct Node-ToNode transmission at exact location-awareness [2] and another one was MANET transmission with MANET route nodes NOT supplied as infrastructure [17]

The feature of location-awareness is concerned with updating location information at good enough refresh rates. The granularity or exactness of this location varies as per technology used. Present levels of technology, nevertheless, operate at extraneously high overheads to obtain high refresh rates, which subsequently pressurise on energy needs. The fact remains that simulation models are important to theoretically delimit bounds of achievements in this research direction, following the assumption that there is significant software ability to channel exact location information into transmission strategies. Following the two strategies of transmission mentioned in previous paragraph, the investigation now required is to experimentally bound the extra energy savings achievable in MANET, with MANET route nodes NOT supplied as infrastructure, compared to direct Node-ToNode transmission. Results of such a study will in turn serve towards enhancement of ubicomp architectures and decide correct channelling of resources needed.

The key contributions of this paper is firstly, the extension of the simple mathematical method, introduced previously [10-13], for calculating the extra amount of savings achievable by overall nodes in MANETs with Route nodes NOT supplied as infrastructure compared to direct node-to-node transmission, with the application of location-aware transmission. Secondly, the model of trend of this extra amount varying over different node numbers in a ubicomp topography of $300 \times 300 \mathrm{~m}^{2}$ is established. The rest of this paper is organised as follows: section 2Experimental Set-up used, section 3- Results Obtained, section 4- Conclusion and References. 
Proc. of The Seventh Intl. Conf. On Advances In Computing, Control And Networking - ACCN 2017 Copyright (C) Institute of Research Engineers and Doctors, USA .All rights reserved. ISBN: 978-1-63248-134-4 doi: 10.15224/ 978-1-63248-134-4-11

\section{Experimental Set-Up Used.}

The same experimental design used in previous paper $[10]$ and referred to in another previous papers $[62,63$, 64] is re-used here.

The metric of concern for this set of experiment is OLNTNES [16].

\section{Results Obtained.}

The study here is split into four subsections: OLNTNES Minimum BAEF (Min_BAEF), OLNTNES Mean BAEF (MBAEF), OLNTNES Maximum BAEF (Max_BAEF) and certain critical values obtainable. The work is basically some further processing applied over certain results obtained previously. Floating points Values instead of integers, are used to get exact results for processing.

\subsection{OLNTNES Min_BAEF}

This section follows from section 3.1 in previous paper [49], i.e. OLNTNES critical value 1, representing minimum value of OLNTNES reached. Minimum OLNTNES is obtained in a situation of maximum value of Overall less node-to-node energy consumption (OLNTNEC). OLNTNES Min_BAEF is computed as:

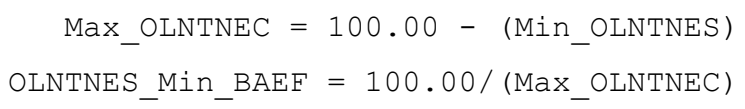

The corresponding values for node number 7 until 56 and the applicable graphical plot is given in figure 1 .

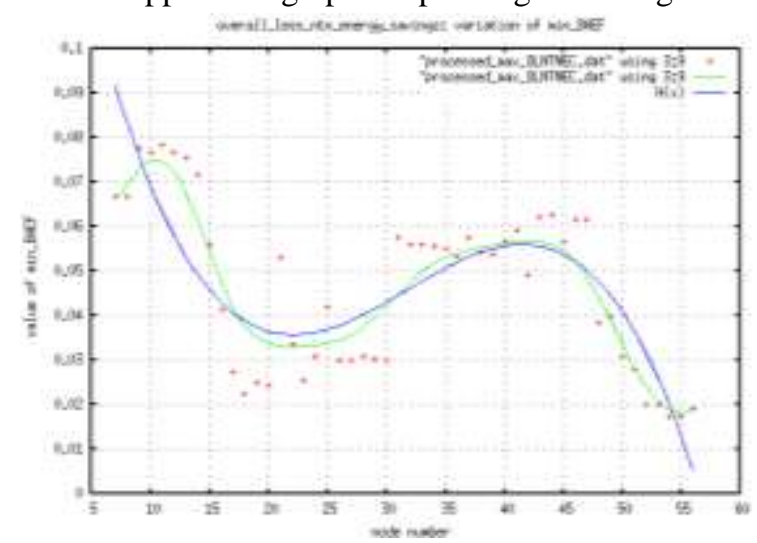

Figure 1: OLNTNES Min_BAEF

The equation of best fit is reworked as:

$H(x)=a * \sin (b *(x+c))+(d * x)+f$

The ch_sq is 0.000130468 . The parameters of fit are: $\mathrm{a}=-2091.55, \mathrm{~b}=-0.00251564, \mathrm{c}=-31.7908, \mathrm{~d}=$ $5.26001, f=167.266$

The pertinent observation here, is that all values are below 0.1 which depicts worst case situation that some nodes may have their BAEF reduced to below one tenth of its value in direct NTN transmission strategy.

\subsection{OLNTNES MBAEF}

This section follows from section 2.3 in previous paper [33], i.e. OLNTNES parameter c of OLNTNES equation of trend. Corresponding Modal BAEF is computed as follows:

Modal_OLNTNEC $=100.00-($ Modal OLNTNES $)$ OLNTNES_Modal_BAEF $=100.00 /$ (Modal_OLNTNEC)

The values of OLNTNES_Modal_BAEF were computed for node numbers 7 until 56 and corresponding plot is given in figure 2 .

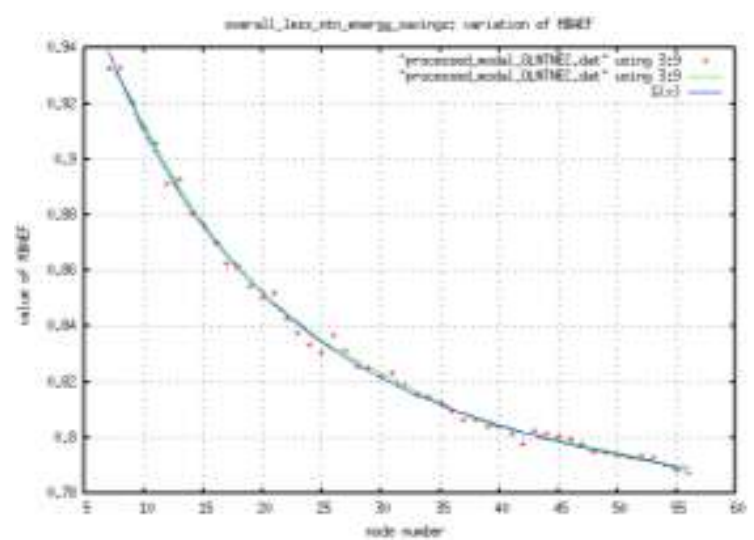

Figure 2: OLNTNES MBAEF

The equation of best fit here, $\mathrm{G}(\mathrm{x})$, has also followed similar computation over $\mathrm{F}(\mathrm{x})$ obtained in section 2.3 of previous paper [33], retaining the values of parameters $\mathrm{a}, \mathrm{b}, \mathrm{c}$ and $\mathrm{d}$.

$$
\begin{aligned}
& F(x)=a^{\star} x^{1.5} \star \exp \left(b * x^{0.5}\right)+\left(c^{\star} x\right)+d \\
& G(x)=100.00 /(100.00-F(x))
\end{aligned}
$$

The pertinent observation here, is that all values are below 1, i.e. Modal number of nodes will have their battery availability reduced rather than extended. This tends to be more severe with increasing node number.

\subsection{OLNTNES Max_BAEF.}

This section follows from section 3.2 in previous paper [49], i.e. OLNTNES critical value 2 representing highest value of OLNTNES reached. Maximum OLNTNES is obtained corresponding to minimum sender less Node-to-Node Energy consumed, OLNTNEC. Max_BAEF is computed as follows:

$$
\begin{gathered}
\text { Min_OLNTNEC }=100.00-(\text { Max_OLNTNES }) \\
\text { OLNTNES_Max_BAEF }=100.00 /(\text { Min_OLNTNEC) }
\end{gathered}
$$

The values of OLNTNES Max_BAEF were computed for node numbers 7 until 56 and corresponding plot is given in figure 3 .

The equation of best fit, $\mathrm{H}(\mathrm{x})$, is reworked as

$H(x)=a^{*} \sin \left(b^{*}(x+c)\right)+\left(d^{*} x\right)+f$ 
Proc. of The Seventh Intl. Conf. On Advances In Computing, Control And Networking - ACCN 2017 Copyright (C) Institute of Research Engineers and Doctors, USA .All rights reserved.

ISBN: 978-1-63248-134-4 doi: 10.15224/ 978-1-63248-134-4-11

The ch_sq is 0.0524144 . The parameters of fit are: $\mathrm{a}=0.391957, \mathrm{~b}=-0.181283, \mathrm{c}=34.4959, \mathrm{~d}=0.023$ $2485, \mathrm{f}=2.51495$

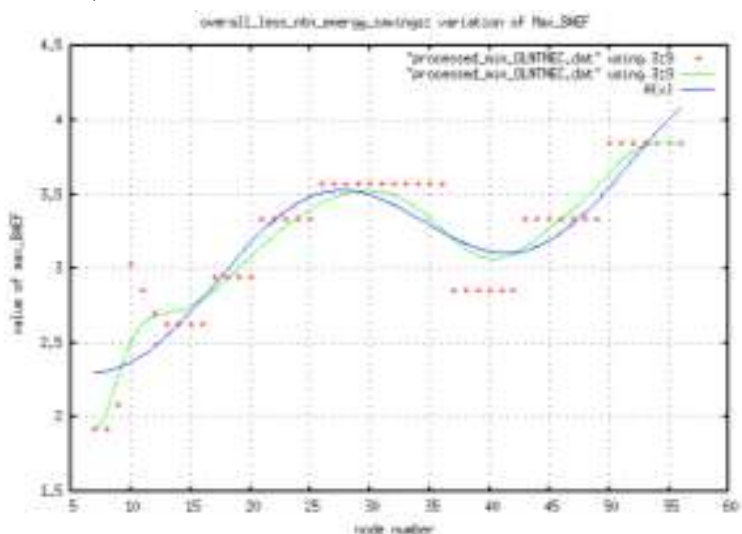

Figure 3: OLNTNES Max_BAEF Trend

\subsection{Certain OLNTNES BAEF Critical Values.}

Five critical values have been identified as presented in Table 1, which correspond to certain critical values studied previously [49]. Colum headings are: $\mathrm{C} 1 \rightarrow$ OLNTNES BAEF critical value, $\mathrm{C} 2 \rightarrow$ Meaning of OLNTNES BAEF critical value, $\mathrm{C} 3 \rightarrow$ section in previous paper [49] the OLNTNES BAEF critical value corresponds to.

\begin{tabular}{|c|l|c|}
\hline C1 & C2 & C3 \\
\hline 1 & $\%$ nodes with BAEF < MBAEF. & 3.4 \\
\hline 2 & $\%$ nodes with BAEF > MBAEF. & 3.5 \\
\hline 3 & $\%$ nodes with BAEF < 1 & 3.6 \\
\hline 4 & $\%$ nodes with BAEF $=1$ & 3.7 \\
\hline 5 & $\%$ nodes with BAEF > 1 & 3.8 \\
\hline
\end{tabular}

Table 1: OLNTNES BAEF Critical Values

\section{Conclusion.}

This piece of investigation has depicted the extension of a mathematical method for predicting the extents to which user nodes' battery availability could be extended using location-aware transmission strategy in MANETs over a ubicomp topography of $300 \times 300 \mathrm{~m}^{2}$ over varying node densities. MANET nodes are assumed to be other user nodes and NOT supplied as infrastructure nodes in this investigation. The method extended here has been applied over results reported in previous papers [17, 33, 49]. This paper contributes more to the study of ubicomp environment from a software engineering perspective. It also offers some supplementary components for prediction and calibrating reliability of ubicomp environments. Certain new metrics developed previously [10] to heighten the subfield of models in ubicomp and to better shape future architecture of ubicomp.

This study is built over a prior empirical investigation performed in simulator software NS-2 over Linux. Graphical analysis software opted was gnuplot.
Floating point calculations have been used to derive accurate answers. This study is geared at depicting values of BAEF in an impartial mathematical way. Interpretation of values and trends reported, are not given here such as good/bad or workable/unworkable or worthy/unworthy to invest in. Designers are free to interpret as per their own analysis.

Further work identified remains further polishing of the model and equations of trends obtained and applying more rigorous software engineering validation approaches to the metrics defined and extended here.

\section{References}

[1] M. Kaleem GALAMALI, Assoc. Prof Nawaz MOHAMUDALLY, Towards Dependable Pervasive Systems-A Position and Vision Paper, CEET 2014

[2] M. Kaleem GALAMALI, Assoc. Prof Nawaz MOHAMUDALLY, Model of Energy Savings achievable with Location-aware Node-to-Node Transmission in UbiComp , CEET 2014

[3] M. Kaleem GALAMALI, Assoc. Prof Nawaz MOHAMUDALLY, Model of Energy Savings achievable with Location-aware Node-to-Node Transmission in UbiComp Using Location Refresh Intervals, CEET 2014

[4] M. Kaleem GALAMALI, Assoc. Prof Nawaz MOHAMUDALLY, Model of Energy Savings achievable with Location-aware Transmission in UbiComp Using Relays, CEET 2014

[5] M. Kaleem GALAMALI, Assoc. Prof Nawaz MOHAMUDALLY, Mathematical modeling of need of exact number of relays to ensure seamless mobility in mobile computing, CEET 2014

[6] M. Kaleem GALAMALI, Assoc. Prof Nawaz MOHAMUDALLY, Modelling of need for multiple relays for ensuring seamless mobility, CEET 2014

[7] M. Kaleem GALAMALI, Assoc. Prof Nawaz MOHAMUDALLY, Investigation of prominence of placements of relays in a ubicomp topography,

[8] M. Kaleem GALAMALI, Assoc. Prof Nawaz MOHAMUDALLY, Model of energy savings achievable with location-aware transmission in ubicomp using optimised number of relays.

[9] M. Kaleem GALAMALI, Assoc. Prof Nawaz MOHAMUDALLY, Investigation of Prominence of Placements of Optimised Number of Relays in a Ubicomp Topography using Location-Aware Transmission, CEET 2015.

[10] M. Kaleem GALAMALI, Assoc. Prof Nawaz MOHAMUDALLY, Extending Node Battery Availability in Ubicomp with Location-Aware Transmission, CEET 2015.

[11] M. Kaleem GALAMALI, Assoc. Prof Nawaz MOHAMUDALLY, Extending Node Battery Availability in Ubicomp with Location-Aware Transmission using Location Refresh Intervals, CEET 2015.

[12] M. Kaleem GALAMALI, Assoc. Prof Nawaz MOHAMUDALLY, Extending Node Battery Availability in Ubicomp with Location-Aware Transmission using Uniformly Placed Relays, CEET 2015.

[13] M. Kaleem GALAMALI, Assoc. Prof Nawaz MOHAMUDALLY, Extending Node Battery Availability in Ubicomp with Location-Aware Transmission Using Optimally Placed Relays, CEET 2015.

[14] M. Kaleem GALAMALI, Assoc. Prof Nawaz MOHAMUDALLY, Model of Sender Node Energy Savings Achievable with Location-Aware MANET Transmission in Ubicomp. ACCN 2016

[15] M. Kaleem GALAMALI, Assoc. Prof Nawaz MOHAMUDALLY, Model of Overall Node Energy Savings Achievable with Location-Aware MANET Transmission in Ubicomp. ACCN 2016 
[16] M. Kaleem GALAMALI, Assoc. Prof Nawaz MOHAMUDALLY, Model of Sender Node Extra Energy Savings Achievable in MANET Against Direct Node-to-Node Transmission Using Location-Aware Transmission in Ubicomp. ACCN 2016

[17] M. Kaleem GALAMALI, Assoc. Prof Nawaz MOHAMUDALLY, Model of Overall Node Extra Energy Savings Achievable in MANET against Direct Node-to-Node Transmission Using Location-Aware Transmission in Ubicomp. ACCN 2016

[18] M. Kaleem GALAMALI, Assoc. Prof Nawaz MOHAMUDALLY, Model of Energy Consumption Ratio Achievable in MANET Using Location-Aware Transmission in Ubicomp. ACCN 2016

[19] M. Kaleem GALAMALI, Assoc. Prof Nawaz MOHAMUDALLY, Model of Minimum Energy Consumption Ratio Achievable in MANET Using LocationAware Transmission in Ubicomp. ACCN 2016

[20] M. Kaleem GALAMALI, Assoc. Prof Nawaz MOHAMUDALLY, Model of Maximum Energy Consumption Ratio Achievable in MANET Using LocationAware Transmission in Ubicomp. ACCN 2016

[21] M. Kaleem GALAMALI, Assoc. Prof Nawaz MOHAMUDALLY, Model of Overall Energy Consumption Fairness Ratio Achievable in MANET Using Location-Aware Transmission in Ubicomp. ACCN 2016

[22] M. Kaleem GALAMALI, Assoc. Prof Nawaz MOHAMUDALLY, Model of Overall Energy Consumption Fairness Proportion Achievable in MANET Using LocationAware Transmission for Ubicomp, CEET 2016

[23] M. Kaleem GALAMALI, Assoc. Prof Nawaz MOHAMUDALLY, Model of Minimum Fairness Proportion Achievable in MANET Using Location-Aware Transmission for Ubicomp, CEET 2016

[24] M. Kaleem GALAMALI, Assoc. Prof Nawaz MOHAMUDALLY, Model of Maximum Fairness Proportion Achievable in MANET Using Location-Aware Transmission for Ubicomp, CEET 2016

[25] M. Kaleem GALAMALI, Assoc. Prof Nawaz MOHAMUDALLY, Model of Sender Fairness Proportion Achievable in MANET Using Location-Aware Transmission for Ubicomp, CEET 2016

[26] M. Kaleem GALAMALI, Assoc. Prof Nawaz MOHAMUDALLY, Model of Distance Travelled by packets in MANETs using Location-Aware Transmission for Ubicomp, CEET 2016

[27] M. Kaleem GALAMALI, Assoc. Prof Nawaz MOHAMUDALLY, Model of Maximum CBR Distance Travelled by packets in MANETs using Location-Aware Transmission for Ubicomp, CEET 2016

[28] M. Kaleem GALAMALI, Assoc. Prof Nawaz MOHAMUDALLY, Model of Minimum CBR Distance Travelled by packets in MANETs using Location-Aware Transmission for Ubicomp, CEET 2016

[29] M. Kaleem GALAMALI, Assoc. Prof Nawaz MOHAMUDALLY, Model of Range CBR Distance Experienced by Transmissions in MANETs using LocationAware Transmission for Ubicomp, CEET 2016

[30] M. Kaleem GALAMALI, Assoc. Prof Nawaz MOHAMUDALLY, Trend Analyses of Parameters of Equations for Sender Node Energy Savings Achievable in ubicomp MANETs using Location-Aware Transmission, ACCN 2017.

[31] M. Kaleem GALAMALI, Assoc. Prof Nawaz MOHAMUDALLY, Trend Analyses of Parameters of Equations for Overall Node Energy Savings Achievable in ubicomp MANETs using Location-Aware Transmission, ACCN 2017.

[32] M. Kaleem GALAMALI, Assoc. Prof Nawaz MOHAMUDALLY, Trend Analyses of Parameters of Equations for Sender Node Extra Energy Savings Achievable in MANET against Direct Node-to-Node Location-Aware Transmission, ACCN 2017.

[33] M. Kaleem GALAMALI, Assoc. Prof Nawaz MOHAMUDALLY, Trend Analyses of Parameters of Equations for Overall Nodes Extra Energy Savings Achievable in MANET against Direct Node-to-Node Location-Aware Transmission, ACCN 2017.

[34] M. Kaleem GALAMALI, Assoc. Prof Nawaz
MOHAMUDALLY, Trend Analyses of Parameters of Equations for Energy Consumption Ratio Achievable in Ubicomp MANET Using Location-Aware Transmission, ACCN 2017.

[35] M. Kaleem GALAMALI, Assoc. Prof Nawaz MOHAMUDALLY, Trend Analyses of Parameters of Equations for Minimum Energy Consumption Ratio Achievable in Ubicomp MANETs Using Location-Aware Transmission, ACCN 2017.

[36] M. Kaleem GALAMALI, Assoc. Prof Nawaz MOHAMUDALLY, Trend Analyses of Parameters of Equations for Maximum Energy Consumption Ratio Achievable in Ubicomp MANETs Using Location-Aware Transmission, ACCN 2017.

[37] M. Kaleem GALAMALI, Assoc. Prof Nawaz MOHAMUDALLY, Trend Analyses of Parameters of Equations for Overall Fairness Ratio Achievable in Ubicomp MANETs Using Location-Aware Transmission, ACCN 2017.

[38] M. Kaleem GALAMALI, Assoc. Prof Nawaz MOHAMUDALLY, Trend Analyses of Parameters of Equations for Energy Consumption Fairness Proportion Achievable in Ubicomp MANETs Using Location-Aware Transmission, CEET 2017

[39] M. Kaleem GALAMALI, Assoc. Prof Nawaz MOHAMUDALLY, Trend Analyses of Parameters of Equations for Minimum Fairness Proportion Achievable in Ubicomp MANETs Using Location-Aware Transmission, CEET 2017

[40] M. Kaleem GALAMALI, Assoc. Prof Nawaz MOHAMUDALLY, Trend Analyses of Parameters of Equations for Maximum Fairness Proportion Achievable in Ubicomp MANETs Using Location-Aware Transmission, CEET 2017

[41] M. Kaleem GALAMALI, Assoc. Prof Nawaz MOHAMUDALLY, Trend Analyses of Parameters of Equations for Sender Fairness Proportion Achievable in Ubicomp MANETs Using Location-Aware Transmission, CEET 2017

[42] M. Kaleem GALAMALI, Assoc. Prof Nawaz MOHAMUDALLY, Trend Analyses of Parameters of Equations for Packets Per Distance Achievable in Ubicomp MANETs Using Location-Aware Transmission, CEET 2017

[43] M. Kaleem GALAMALI, Assoc. Prof Nawaz MOHAMUDALLY, Trend Analyses of Parameters of Equations for Maximum CBR Distance Achievable in Ubicomp MANETs Using Location-Aware Transmission, CEET 2017

[44] M. Kaleem GALAMALI, Assoc. Prof Nawaz MOHAMUDALLY, Trend Analyses of Parameters of Equations for Minimum CBR Distance Achievable in Ubicomp MANETs Using Location-Aware Transmission, CEET 2017

[45] M. Kaleem GALAMALI, Assoc. Prof Nawaz MOHAMUDALLY, Trend Analyses of Parameters of Equations for Range CBR Distance Achievable in Ubicomp MANETs Using Location-Aware Transmission, CEET 2017

[46] M. Kaleem GALAMALI, Assoc. Prof Nawaz MOHAMUDALLY, Trend Analyses of Critical Values Obtained for Sender Node Energy Savings Achievable in Ubicomp MANETs Using Location-Aware Transmission, CEET 2017

[47] M. Kaleem GALAMALI, Assoc. Prof Nawaz MOHAMUDALLY, Trend Analyses of Critical Values Obtained for Overall Node Energy Savings Achievable in Ubicomp MANETs Using Location-Aware Transmission, CEET 2017

[48] M. Kaleem GALAMALI, Assoc. Prof Nawaz MOHAMUDALLY, Trend Analyses of Critical Values Obtained for Sender Node Extra Energy Savings Achievable in Ubicomp MANET Against Direct Node-to-Node LocationAware Transmission, CEET 2017

[49] M. Kaleem GALAMALI, Assoc. Prof Nawaz MOHAMUDALLY, Trend Analyses of Critical Values Obtained for Overall Nodes Extra Energy Savings Achievable in Ubicomp MANET Against Direct Node-to-Node LocationAware Transmission, CEET 2017

[50] M. Kaleem GALAMALI, Assoc. Prof Nawaz MOHAMUDALLY, Trend Analyses of Critical Values Obtained for Energy Consumption Ratio Achievable in Ubicomp MANETs Using Location-Aware Transmission Strategies, CEET 2017

[51] M. Kaleem GALAMALI, Assoc. Prof Nawaz MOHAMUDALLY, Trend Analyses of Critical Values 
Obtained for Minimum Energy Consumption Ratio Achievable in Ubicomp MANETs Using Location-Aware Transmission Strategies, CEET 2017

[52] M. Kaleem GALAMALI, Assoc. Prof Nawaz MOHAMUDALLY, Trend Analyses of Critical Values Obtained for Maximum Energy Consumption Ratio Achievable in Ubicomp MANETs Using Location-Aware Transmission Strategies, CEET 2017

[53] M. Kaleem GALAMALI, Assoc. Prof Nawaz MOHAMUDALLY, Trend Analyses of Critical Values Obtained for Overall Fairness Ratio Achievable in Ubicomp MANETs Using Location-Aware Transmission Strategies, CEET 2017

[54] M. Kaleem GALAMALI, Assoc. Prof Nawaz MOHAMUDALLY, Trend Analyses of Critical Values Obtained for Energy Consumption Fairness Proportion Achievable in Ubicomp MANETs Using Location-Aware Transmission Strategies, ACCN 2017.

[55] M Kaleem GALAMALI, Assoc Prof Nawaz MOHAMUDALLY, Trend Analyses of Critical Values Obtained for Minimum Fairness Proportion Achievable in Ubicomp MANETs Using Location-Aware Transmission Strategies, ACCN 2017.

[56] M. Kaleem GALAMALI, Assoc. Prof Nawaz MOHAMUDALLY, Trend Analyses of Critical Values Obtained for Maximum Fairness Proportion Achievable in Ubicomp MANETs Using Location-Aware Transmission Strategies, ACCN 2017.

[57] M. Kaleem GALAMALI, Assoc. Prof Nawaz MOHAMUDALLY, Trend Analyses of Critical Values Obtained for Sender Fairness Proportion Achievable in Ubicomp MANETs Using Location-Aware Transmission Strategies, ACCN 2017.

[58] M. Kaleem GALAMALI, Assoc. Prof Nawaz MOHAMUDALLY, Trend Analyses of Critical Values Obtained for Packets Per Distance Achievable in Ubicomp MANETs Using Location-Aware Transmission Strategies, ACCN 2017.

[59] M. Kaleem GALAMALI, Assoc. Prof Nawaz MOHAMUDALLY, Trend Analyses of Critical Values Obtained for Maximum CBR Distance Achievable in Ubicomp MANETs Using Location-Aware Transmission Strategies, ACCN 2017.

[60] M. Kaleem GALAMALI, Assoc. Prof Nawaz MOHAMUDALLY, Trend Analyses of Critical Values Obtained for Minimum CBR Distance Achievable in Ubicomp MANETs Using Location-Aware Transmission Strategies, ACCN 2017.

[61] M. Kaleem GALAMALI, Assoc. Prof Nawaz MOHAMUDALLY, Trend Analyses of Critical Values Obtained for Range CBR Distance Achievable in Ubicomp MANETs Using Location-Aware Transmission Strategies, ACCN 2017.

[62] M. Kaleem GALAMALI, Assoc. Prof Nawaz MOHAMUDALLY, Extending Sender Node Battery Availability in Ubicomp with Location-Aware MANET Transmission, ACCN 2017.

[63] M. Kaleem GALAMALI, Assoc. Prof Nawaz MOHAMUDALLY, Extending Overall Node Battery Availability in Ubicomp with Location-Aware MANET Transmission, ACCN 2017.

[64] M. Kaleem GALAMALI, Assoc. Prof Nawaz MOHAMUDALLY, Extension of Sender Node Battery Extra Availability in Ubicomp with Location-Aware MANET Transmission Compared to Direct Node-To-Node Transmission, ACCN 2017.

[65] Markus Bylund and Zary Segall, Towards seamless mobility with personal servers, 2004.

[66] Masugi Inoue, Mikio Hasegawa, Nobuo Ryoki and Hiroyuki Morikawa, Context-Based Seamless Network and Application Control, 2004

[67] Xiang Song, Umakishore Ramachandran, MobiGo: A Middleware for Seamless Mobility, College of Computing Georgia Institute of Technology, Atlanta, GA, USA, August 2007

[68] Budzisz, Ferrús, R., Brunstrom A., Grinnemo, K, Fracchia, R., Galante, G., and Casadevall, F. Towards transport-layer mobility: Evolution of SCTP multihoming, March 2008

[69] Paul Dourish \& Genevieve Bell, Divining a digital future, 2011.

[70] Xiang Song, Seamless Mobility In Ubiquitous Computing Environments, PhD Thesis, Georgia Institute of Technology, August 2008

[71] Kevin O Mahony, Jian Liang, Kieran Delaney, User-Centric Personalization and Autonomous Reconfiguration Across Ubiquitous Computing Environments, NIMBUS Centre Cork
Institute of Technology, Cork, Ireland, UBICOMM 2012

[72] Pablo Vidales, Seamless mobility in 4G systems, Technical Report, University of Cambridge, Computer Laboratory, Number 656, November 2005

[73] João Pedro Sousa and David Garlan, Aura: An Architectural Framework for User Mobility in Ubiquitous Computing Environments, School of Computer Science, Carnegie Mellon University, USA, August 2002

[74] Dennis Lupiana, Ciaran O'Driscoll, Fredrick Mtenzi, Defining Smart Space in the Context of Ubiquitous Computing, Dublin Institute of Technology, Ireland, Special Issue on ICIT 2009 Conference - Web and Agent Systems, 2009

[75] N.S.V.Shet1, Prof.K.Chandrasekaran2 and Prof. K.C.Shet3, WAP Based Seamless Roaming In Urban Environment with Wise Handoff Technique, International Journal of UbiComp (IJU), Vol.1, No.4, October 2010

[76] Yipeng Yu Dan He Weidong Hua Shijian Li Yu Qi Yueming Wang Gang Pan, FlyingBuddy2: A Brain-controlled Assistan for the Handicapped, Zhejiang University, UbiComp'12, September 5-8, 2012

[77] Jing Su, James Scott, Pan Hui, Jon Crowcroft, Eyal de Lara Christophe Diot, Ashvin Goel, Meng How Lim, and Eben Upton, Haggle: Seamless Networking for Mobile Applications, 2007

[78] Rui Han, Moustafa M. Ghanem, Li Guo, Yike Guo*, Michelle Osmond, Enabling cost-aware and adaptive elasticity of multi-tier cloud applications, Future Generation Computer Systems, 2012

[79] Byrav Ramamurthy, K. K. Ramakrishnan, Rakesh K. Sinha, Cost and Reliability Considerations in Designing the NextGeneration IP over WDM Backbone Networks, 2012.

[80] Bhavish Aggarwal, Aditya Akella, Ashok Anand, Athula Balachandran, Pushkar Chitnis, Chitra Muthukrishnan, Ram Ramjee and George Varghese, EndRE: An End-System Redundancy Elimination Service for Enterprises, NSDI 2010, San Jose, CA

[81] Ashok Anand, Vyas Sekar and Aditya Akella, SmartRE: An Architecture for Coordinated Network-wide Redundancy Elimination, SIGCOMM 2009, Barcelona, Spain

[82] John Breeden II, "Smart-phone battery life could double without better batteries", Nov 14, 2012

[83] Andy Boxall, "When will your phone battery last as long as your kindle", December 5, 2012.

[84] Imielinski, T. and Navas, J.C. (1999). GPS-based geographic addressing, routing, and resource discovery. Comms. ACM, Vol. 42, No. 4, pp. 86-92.

[85] Hightower, J. and Borriello, G. (2001). Location Systems for Ubiquitous Computing. IEEE Computer, Vol. 34, No. 8 , August, pp. 57-66.

[86] Harter, A., Hopper, A., Steggles, P., Ward, A. and Webster, P. (2002). The Anatomy of a Context-Aware Application. Wireless Networks, Vol. 8, No. 2-3, Mar-May, pp. 187-197.

[87] Hightower, J., Brumitt, B. and Borriello, G. (2002). The Location Stack: A Layered Model for Location in Ubiquitous Computing. Proceedings of the 4th IEEE Workshop on Mobile Computing Systems \& Applications (WMCSA 2002), Callicoon, NY, USA, June, pp. 22-28

[88] Graumann, D., Lara, W., Hightower, J. and Borriello, G. (2003). Real-world implementation of the Location Stack: The Universal Location Framework. Proceedings of the 5th IEEE Workshop on Mobile Computing Systems \& Applications (WMCSA 2003), Monterey, CA, USA, October, pp. 122-128.

[89] Ko, Y., \& Vaidya, N. H. (2000). Location-aided routing (LAR) in mobile ad hoc networks. Wireless Networks, 6(4), 307-321.

[90] Liao, W.-H., Tseng, Y.-C., \& Sheu, J.-P. (2001). GRID: a fully location-aware routing protocol for mobile ad hoc networks. Telecommunication Systems, 18(1), 37-60.

[91] Kuhn, F., Wattenhofer, R., Zhang, Y., \& Zollinger, A. (2003). Geometric ad-hoc routing: of theory and practice. In Proceedings of the ACM (PODC'03) (pp. 63-72).

[92] Jiang, X., \& Camp, T. (2002). Review of geocasting protocols for a mobile ad hoc network. In Proceedings of the Grace Hopper Celebration (GHC).

[93] Ko, Y. \& Vaidya, N. H. (1999). Geocasting in mobile ad hoc networks: location-based multicast algorithms. In Proceedings of the IEEE (WMCSA'99) (pp. 101). 
[94] Mauve, M., Fuler, H., Widmer, J., \& Lang, T. (2003). Position-based multicast routing for mobile ad-hoc networks (Technical Report TR-03-004). Department of Computer Science, University of Mannheim.

[95] Xu, Y., Heidemann, J., \& Estrin, D. (2001). Geographyinformed energy conservation for adhoc routing. In Proceedings of the ACM/IEEE (MOBICOM'01) (pp. 70-84).

[96] Hu, Y.-C., Perrig, A., \& Johnson, D. (2003). Packet leashes: a defense against wormhole attacks in wireless ad hoc networks. In Proceedings of the INFOCOM' 03 (pp. 1976-1986).

[97] Patwari, N., Hero III, A. O., Perkins, M., Correal, N. S., \& O'Dea, R. J. (2003). Relative location estimation in wireless sensor networks. IEEE Transactions on Signal Processing, 51(8), 2137-2148.

[98] Baldauf, M., Dustdar, S., \& Rosenberg, F. (2007). A Survey on Context Aware Systems. International Journal of Ad Hoc and Ubiquitous Computing, Inderscience Publishers. forthcoming. Pre-print from: http://www.vitalab.tuwien.ac.at/ florian/papers/ijahuc2007.pdf

[99] Hong, D., Chiu, D.K.W., \& Shen, V.Y. (2005). Requirements elicitation for the design of context-aware applications in a ubiquitous environment. In Proceedings of ICEC'05 (pp. 590-596).

[100] Neeraj Tantubay, Dinesh Ratan Gautam and Mukesh Kumar Dhariwal, A Review of Power Conservation in Wireless Mobile Ad hoc Network (MANET)", International Journal of computer Science Issues, Vol 8, Issue 4, No 1, July 2011.

[101] Wenrui Zhao, Mostafa Ammar and Ellen Zegura, "A Message Ferrying Approach for Data Delivery in Sparse Mobile Ad Hoc Networks", MobiHoc'04, May 24-26, 2004, Roppongi, Japan.

[102] Sgroi et al., "Designing Wireless Protocols: Methodology and Applications, February 2000.

[103] Gyula et al., "Simulation-based optimization of communication protocols for large-scale wireless sensor networks", 10 October 2002

[104] Rao and Sharma, "Cross Layer Protocols For Multimedia Transmission in Wireless Networks", June 2012

[105] Herms et al, "Realism in Design and Evaluation of Wireless Routing Protocols", 2007.

[106] Nitin Jain, Dr S.N. Panda, Dr Ashok Kumar, "Future scintillation of ubiquitous computing", September 2012

About Author (s):

Associate Professor Nawaz Mohamudally works at University of Technology, Mauritius (UTM) and has undertaken supervision of MPhil/PhD Students for many years.

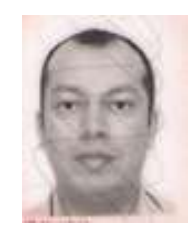

M. Kaleem Galamali is a part-time student (achieved M Phil Transfer on 28.10.2014, currently PhD student) at UTM under supervision of A.P. Nawaz Mohamudally. 